Arq. Bras. Med. Vet. Zootec., v.73, n.1, p.256-260, 2021

\title{
Communication
}

[Comunicação]

\section{Lentivirus vectors fail to deliver transgenes into bovine zygotes after co-incubation with sperm during in vitro fertilization}

[Lentivirus falham na entrega de transgenes em zigotos bovinos após coincubação com espermatozoide, durante fertilização in vitro]

\section{D.R. Lemos $^{1}$, G.T. Souza ${ }^{2}$, V.G.P. Souza ${ }^{3}$, L.S. Ribeiro ${ }^{4}$, N.Z. Saraiva ${ }^{5}$, C.C.R. Quintão ${ }^{5}$, L.S.A. Camargo ${ }^{5 *}$}

\author{
${ }^{1}$ Aluno de pós-graduação - Universidade Federal de Viçosa - Viçosa, MG \\ ${ }^{2}$ Aluno de pós-graduação - Instituto de Ciências Biológicas - Universidade Federal \\ de Juiz de Fora - Juiz de Fora, MG
}

${ }^{3}$ Aluno de pós-graduação - Instituto de Biociências - Universidade Estadual Paulista - Botucatu, SP

${ }^{4}$ Aluno de pós-graduação - Faculdade de Veterinária - Universidade Federal Fluminense - Niterói, RJ

${ }^{5}$ Empresa Brasileira de Pesquisa Agropecuária - Juiz de Fora, MG

The introduction of a foreign DNA in the livestock genome opens the opportunity not only to improve traits of interest but also to produce biopharmaceuticals by large animals (Kues and Niemann, 2011, Bertolini et al., 2016). However, the low efficiency of gene delivery systems in farm animals (Galli et al., 2012, Bertolini et al., 2016) has undermined the progress of livestock transgenesis. Transduction systems using retro/lentivirus has been shown to be one of the alternatives to deliver foreign DNA to bovine embryos in order to generate transgenic calves (Hofmann et al., 2004). However, zona pellucida (ZP) is a barrier for penetration of lentiviral vectors (LVs), which requires microinjection of viral particles into the perivitelline space (Pfeifer and Hofmann, 2009).

Later was reported that LV could interact with fresh semen and produce transgenic pigs after insemination (Zhang et al., 2012), overcoming the ZP barrier, but there are no reports in cattle. Therefore, the aim of this study was to evaluate whether LV can be delivered into zygotes during in vitro fertilization (IVF) or into presumptive zygotes during in vitro culture (IVC) to generate genetically modified bovine embryos (GMs). The LVs encoding the genes of green fluorescent protein (GFP) or human coagulation factor IX (FIX), were used in this study.

Recebido em 20 de maio de 2020

Aceito em 8 de setembro de 2020

*Autor para correspondência (corresponding author)

E-mail: camargo3112@gmail.com ; luiz.camargo@embrapa.br
The expression vector containing the FIX gene (GeneID 2158) with goat beta-casein promoter was previously designed using the Vector Builder tool and cloned into a plasmid vector with blasticidin resistance gene to constitute the pLWE2-FIX vector. The GFP expression vector (pLGW-GFP) was derived from pLenti6.2/EmGFP vector (Invitrogen, USA). The expression and packaging vectors (pRSV-Rev; pMDLG / pRRE; pMD2.G; Addgene, USA) were cloned into Escherichia coli DH5-alpha and the plasmids extraction was performed according to the manufacturer's recommendations using the MaxiPrep Kit (Qiagen, USA).

The production of lentiviral vectors was performed with HEK 293 FT cells (ThermoFisher, USA) plated in 6-well plates and cultured in DMEM medium supplemented with $10 \%$ fetal calf serum (FCS) following previous protocol (Wang and Mcmanus., 2009). The cells were cultured until reaching $60 \%$ confluence and then transfected with the expression and packaging vectors ( $4 \mu \mathrm{g}$ each one) using FuGENE HD reagent (Promega, USA) according to manufacturer recommendations. After 48 hours of incubation at $37^{\circ} \mathrm{C}$ and $5 \% \mathrm{CO}_{2}$, the cell culture supernatant was collected and processed using the Lenti-X Concentrator (Clontech, USA), according to manufacturer's instructions and, 
subsequently, the viral concentrates were frozen in a Thermo-Fisher ultra-freezer at $-80^{\circ} \mathrm{C}$.

The titration of the lentiviral vectors was performed by real-time polymerase chain reaction thermocycler (Applied Biosystems, USA) using the PowerUp SYBR Green Master Mix kit (Applied Biosystems). The standard curve was established through serial dilution of vectors, which was related to the number of copies of the plasmid in each dilution. The standard curve obtained via qRT-PCR presented the $\mathrm{R}^{2}$ coefficient value of 0.998083 and the slope coefficient of -4.590497 . Also, the titration of viral particles corresponded to $2.10 \times 10^{6}$ copies $/ \mu \mathrm{L}$. The primers targeting the FIX and GFP genes and the goat beta-casein promoter are shown in Table 1 and they were designed to reach an annealing temperature of $62^{\circ} \mathrm{C}$. The infectivity of LVs was later confirmed in HEK 293 FT cells.

Table 1. Primers designed for lentiviral particles quantification

\begin{tabular}{lcc}
\hline \multicolumn{1}{c}{$\begin{array}{c}\text { Gene targets of the } \\
\text { expression vectors }\end{array}$} & Primers & $\begin{array}{c}\text { Fragment } \\
\text { size (bp) }\end{array}$ \\
\hline $\begin{array}{l}\text { Coagulation factor IX } \\
\text { (pLWE2-FIX) }\end{array}$ & F: TTGCTCCTGTACT GAGGGATA & 112 \\
Goat beta-casein promoter & R: ACGGGTGAGCTTA GAAGTTTG & \\
(pLWE2-FIX) & F: TGAGTTGCGTCTGACTGTTATC & 101 \\
GFP & R: GAAATGCAATCCACTCCAGTATTC & \\
(pLGW-GFP) & F: CACATGAAGCAGC ACGACTT & 214 \\
\hline
\end{tabular}

F: forward sequence; R: reverse sequence; bp: base pair; GFP: green fluorescent protein; FIX: human coagulation factor IX

This study encompassed two experiments, i.e: Experiment 1, LVs were co-incubated with in vitro matured cumulus cells-oocyte complexes (COCs) and sperm during IVF (18h) to compose three groups as follow: IVF-control (IVF with no LV); IVF-FIX (IVF with pLWE2-FIX-LV), and IVF-GFP (IVF with pLGW-GFP-LV); Experiment 2, LVs were co-incubated for $22 \mathrm{~h}$ with partially denuded presumptive zygotes during in vitro culture (IVC) to compose three groups: IVC-control (IVC with no LV); IVC-FIX (IVC with pLWE2-FIX-LV) and IVC-GFP (IVC with pLGW-GFP-LV).

For these experiments, COCs with three or more cumulus cells layers obtained from ovaries collected in a commercial slaughterhouse were matured in vitro for 22 hours at $38.5^{\circ} \mathrm{C}$ under $5 \%$ $\mathrm{CO}_{2}$. The frozen-thawed semen was centrifuged at $3600 \mathrm{~g}$ for $7 \mathrm{~min}$ in Percoll discontinuous density gradient (45-90\%) and the pellet was resuspended in Fert-TALP medium and centrifuged again at $520 \mathrm{~g}$ for $5 \mathrm{~min}$. The in vitro matured COCs were co-incubated for $18 \mathrm{~h}$ with $2 \times 10^{6}$ spermatozoa $/ \mathrm{mL}$ in $100 \mu \mathrm{L}$ drops of Fert-TALP in a humidified atmosphere of $5 \% \quad \mathrm{CO}_{2}$ and $38.5^{\circ} \mathrm{C}$ in air. Afterwards, presumptive zygotes were partially denuded so that less than two cumulus cell layers remained and then they were cultured in a modified CR2aa medium with $5 \% \mathrm{FCS}$ at $38.5^{\circ} \mathrm{C}$ under $5 \% \mathrm{CO}_{2}$, in air. Cleavage rate was evaluated at day four post-fertilization and blastocyst rate was evaluated at day seven and day eight. The LVs were added to IVF or IVC medium at a concentration of $10^{6}$ viral particles $/ \mathrm{mL}$. Cleavage and blastocyst rates were analyzed by Chi-Square and differences were considered significant at the 95\% confidence level $(\mathrm{P}<0.05)$.

The fluorescence signal of GFP protein in embryos and cumulus cells was measured under epifluorescence microscopy and the detection of FIX and GFP genes was assayed by PCR. The embryos and cumulus cells were washed in PBS and rapidly frozen in $0.6 \mathrm{~mL}$ tubes. DNA extraction was performed with $10 \mu \mathrm{L}$ of the DNA extraction solution (5X PCR buffer and 0.2 $\mathrm{mg} / \mathrm{mL}$ proteinase $\mathrm{K}$ ). The samples were incubated for $15 \mathrm{~min}$ at $56^{\circ} \mathrm{C}$ followed by $10 \mathrm{~min}$ at $95^{\circ} \mathrm{C}$. PCR reactions were performed using the Phusion Taq DNA polymerase enzyme and primers (Table 1: coagulation factor IX and GFP primers) according to the following condition: $98^{\circ} \mathrm{C}$ for $30 \mathrm{~s}$ followed by 35 cycles of $98^{\circ} \mathrm{C}$ for 5 $\mathrm{s}, 65^{\circ} \mathrm{C}$ for $10 \mathrm{~s}$ and $72^{\circ} \mathrm{C}$ for $20 \mathrm{~s}$. No-template controls (NTC) were comprised of the PCR reaction mix without nucleic acid, and positive controls were composed of plasmids DNA. The resulting PCR fragments were analyzed in a $2 \%$ agarose gel. 
The co-incubation of LVs with sperm and in vitro matured COCs during IVF (IVF-FIX and IVFGFP groups) decreased $(\mathrm{P}<0.05)$ the blastocyst rates when compared to IVF-control group. The cleavage rate was not significantly affected in
IVF-GFP group, but it was lower $(\mathrm{P}<0.05)$ in IVFFIX than in IVF-control group (Table 2). There was no difference $(\mathrm{P}>0.05)$ on cleavage and blastocyst rates when LVs were co-incubated with presumptive zygotes during IVC (Table 3 ).

Table 2. Effect of lentiviral vectors co-incubation during in vitro fertilization (IVF) on development of bovine embryos

\begin{tabular}{lcccc}
\multicolumn{1}{c}{ Group } & $\mathrm{N}$ & Cleavage $(\%)$ & Blastocyst at D7 (\%) & Blastocyst at D8 (\%) \\
\hline IVF-Control & 111 & $58.56^{\mathrm{a}}$ & $27.63^{\mathrm{a}}$ & $27.63^{\mathrm{a}}$ \\
IVF-FIX & 128 & $43.75^{\mathrm{b}}$ & $5.33^{\mathrm{b}}$ & $6.67^{\mathrm{b}}$ \\
IVF-GFP & 132 & $51.51^{\mathrm{ab}}$ & $7.23^{\mathrm{b}}$ & $6.02^{\mathrm{b}}$ \\
\hline
\end{tabular}

a, b, Different letters among rows indicate difference $(\mathrm{P}<0.05)$, four replicates. GFP: green fluorescent protein; FIX: human coagulation factor IX; N: number of presumptive zygotes.

Table 3. Effect of lentiviral vectors co-incubation during in vitro embryo culture (IVC) on development of bovine embryos

\begin{tabular}{lcccc}
\multicolumn{1}{c}{ Group } & $\mathrm{N}$ & Cleavage $(\%)$ & Blastocyst at D7 $(\%)$ & Blastocyst at D8 (\%) \\
\hline IVC-Control & 65 & 63.08 & 20.83 & 29.17 \\
IVC-FIX & 122 & 60.66 & 22.54 & 25.35 \\
IVC-GFP & 111 & 54.95 & 17.91 & 17.91 \\
\hline
\end{tabular}

No difference exists among rows ( $\mathrm{P}>0.05)$, four replicates. GFP: green fluorescent protein; FIX: human coagulation factor IX; N: number of presumptive zygotes.

The expression of GFP protein was confirmed in cumulus cells on day four and eight postfertilization in IVF-GFP group, but no expression was confirmed in cleaved embryos and blastocysts, as no fluorescence was observed (Figure 1). Products of PCR reactions were visualized with gel electrophoresis. The presence of GFP and FIX gene was detected in samples of cumulus cells from IVC-GFP and IVC-FIX groups. No GFP or FIX gene were detected in cleaved embryos or blastocysts derived from IVFGFP, IVF-FIX, IVC-GFP and IVC-FIX groups (Figure 2).

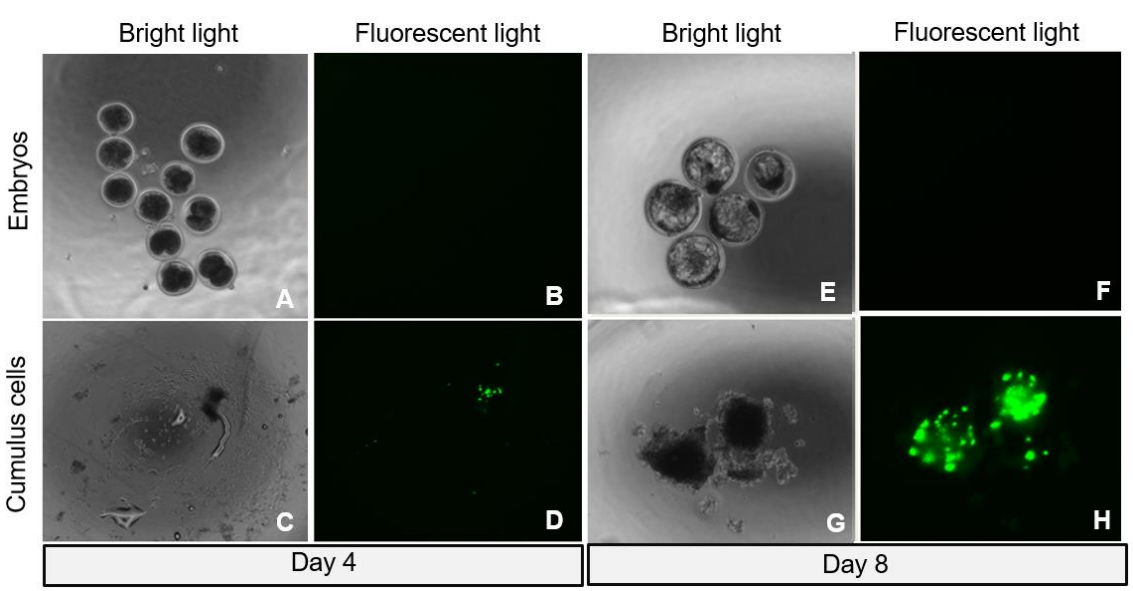

Figure 1. Representative images of bovine embryos and cumulus cells collected at day four and eight postfertilization from group of pLGW-GFP co-incubated with semen during in vitro fertilization (IVF-GFP group). Cleaved embryos under bright light (A) and under fluorescent light (B) showing no protein expression of green fluorescent protein (GFP). Cumulus cells under bright illumination (C) and under fluorescent light (D) showing expression of GFP protein. Blastocysts under bright light (E) and under fluorescent light $(\mathrm{F})$, showing no expression of GFP protein. Cumulus cells under bright light $(\mathrm{G})$ and under fluorescent light $(\mathrm{H})$, showing expression of GFP protein. Magnification 40x 

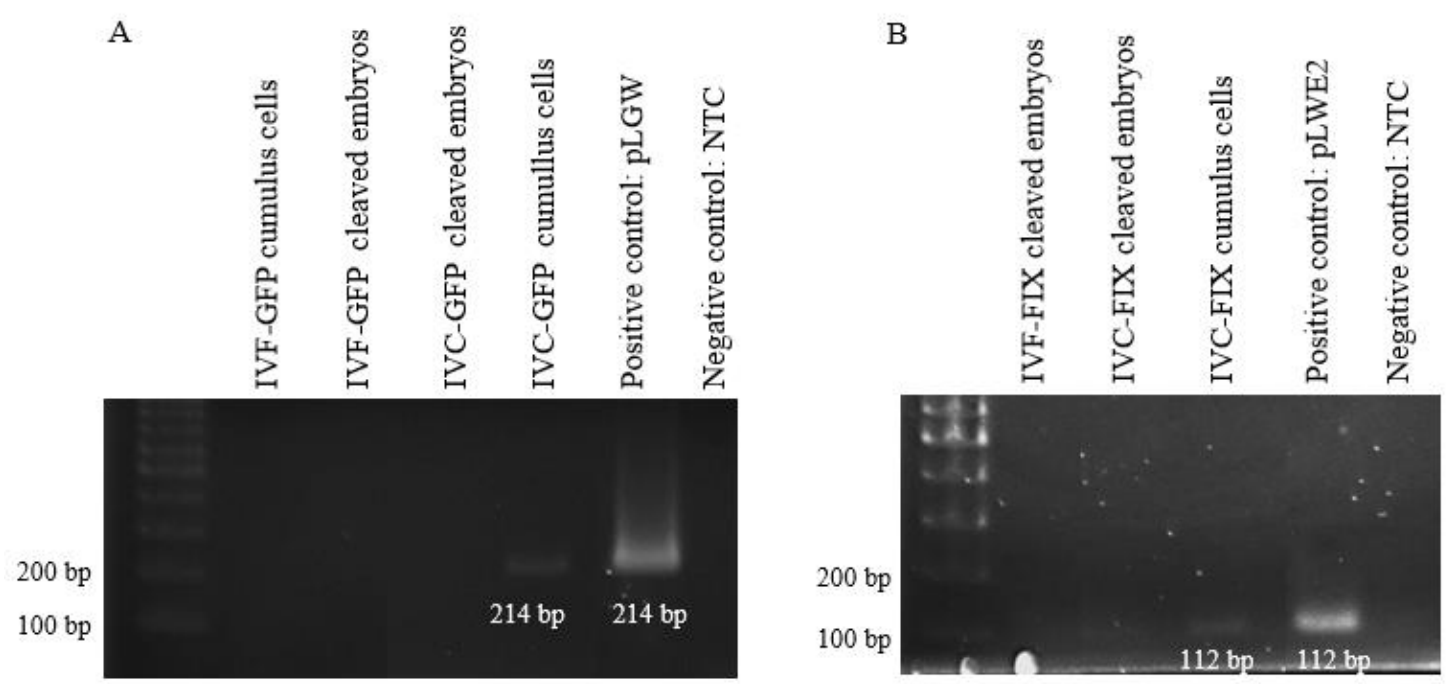

Figure 2. Representative images of agarose gel electrophoresis of PCR fragments targeting green fluorescent protein (GFP; panel A) or coagulation factor IX (FIX; panel B) transgenes in cleaved bovine embryos and cumulus cells. IVF-GFP: in vitro fertilization with pLGW-GFP-LV; IVC-GFP: in vitro embryo culture with pLGW-GFP-LV; IVF-FIX: in vitro fertilization with pLWE2-FIX-LV; IVC-FIX: in vitro embryo culture with pLWE2-FIX-LV. NTC: No template control.

Previous studies showed that LVs need to be microinjected into perivitelline space or coincubated with ZP-free embryos to be effective (Pfeifer and Hofmann, 2009). However, studies with mice reported that LVs carrying GFP gene could be incubated with fresh sperm so that transduced spermatozoa could be used for fertilization and generate GFP-transgenic pups (Chandrashekran et al., 2014, 2016). Also, it was reported that LVs could be associated to porcine fresh sperm and then used for artificial insemination to produce GFP-transgenic piglets (Zhang et al., 2012).

Differently from those previous studies, GFPtransgenic bovine embryos were not found in the present study, despite expression of GFP protein was detected in cumulus cells. Such contrasting results may be due to the distinct approaches used by the studies. While those previous studies coincubated fresh mouse or porcine sperm with LV prior to fertilization or insemination, we coincubated LV with frozen-thawed bovine sperm concomitant with in vitro matured COCs because sperm-LVs co-incubation preceding IVF reduced sperm motility and vigor, making it improper for IVF (data not shown).

The ability of LVs encoding FIX gene to transduce cumulus cells and embryos was investigated by PCR. The presence of FIX gene was confirmed in cumulus cells collected from IVC-FIX group but none of embryos were detected with FIX gene in IVF-FIX or IVC-FIX groups, confirming that LVs were not able to transduce zona intact-embryos. The cleavage and blastocyst production were low when LVs were added to IVF medium for co-incubation with sperm and oocytes. In contrast, LVs added in IVC medium for co-incubation with presumptive zygotes right after IVF did not affect embryo development. Those findings suggest that LVs impair bovine sperm competence during IVF, compromising cleavage and embryo development toward blastocyst stages.

Considering the data together, the co-incubation of LVs during IVF or IVC failed to deliver transgene into bovine embryos, showing that LVs did not associate to sperm in order to pass through zona pellucida. Moreover, LVs during IVF were detrimental for further embryo development, affecting the cleavage and blastocyst rates. Hence, we concluded that LVs co-incubation with frozenthawed bovine sperm concomitant with COCs is not effective to produced genetically modified embryos by means of in vitro fertilization.

Keywords: genetically modified embryos, spermatozoa, gene transfer, lentiviral vector 


\section{RESUMO}

As vantagens dos animais transgênicos têm sido demonstradas em diferentes aplicações, entretanto muitas metodologias usadas para gerar animais geneticamente modificados (GM) apresentam baixas taxas de eficiência. O objetivo deste estudo foi avaliar a entrega dos vetores lentivirais (VLs) em zigotos durante a fertilização in vitro (FIV), para gerar embriões GM, com o gene da proteína verde fluorescente (GFP) ou do fator IX de coagulação humana (FIX). Vetores lentivirais com os genes GFP (pLGW-GFP-LV) ou FIX (pLWE2-FIX-LV) foram utilizados na FIV ou na cultura de embriões in vitro (CIV). A coincubação de pLWE2-FIX-LV com espermatozoides e complexos oócitos-células do cumulus (COCs) durante a FIV diminuiu $(P<0,05)$ as taxas de clivagem e de blastocistos, enquanto com $p L G W$-GFP-LV diminuiu $(P<0,05)$ a taxa de blastocisto quando se comparou ao controle sem VL. A coincubação de pLWE2-FIX-LV e pLGWGFP-LV com presumíveis zigotos durante a CIV não afetou $(P>0,05)$ o desenvolvimento embrionário. $A$ expressão da proteína GFP não foi detectada em embriões após a coincubação de FIV ou CIV, embora as células do cumulus expressassem a proteína até o dia oito de cultivo in vitro. Reações em cadeia da polimerase (PCR) não detectaram os genes GFP ou FIX em embriões, mas ambos foram detectados em células do cumulus. Assim, a coincubação de VL com espermatozoide bovino e COCs não é eficaz para produzir embriões geneticamente modificados por meio de FIV.

Palavras-chave: embriões geneticamente modificados, espermatozoides, transferência gênica, vetores lentivirais

\section{REFERENCES}

BERTOLINI, L.R.; MEADE, H.; LAZZAROTTO, C.R. et al. The transgenic animal platform for biopharmaceutical production. Transgenic Res., v.25, p.329-343, 2016.

CHANDRASHEKRAN, A.; SARKAR, R.; THRASHER, A. et al. Efficient generation of transgenic mice by lentivirus-mediated modification of spermatozoa. FASEB J., v.28, p.569-576, 2014.

CHANDRASHEKRAN, A.; CASIMIR, C.; DIBB, N. et al. Generating transgenic mice by lentiviral transduction and embryo transfer. In: FEDERIZO, M. (Ed.) Lentivirus vectors and exosomes as gene and protein delivery tools. USA: Humana Press, 2016. p.95-106.

GALli, C.; LAGUTINA, I.; PEROTA, A. Somatic cell nuclear transfer and transgenesis in large animals: current and future insights. Reprod. Domest. Anim., v.47, p.2-11, 2012.
HOFMANN, A.; ZAKHARTCHENKO, V.; WEPPERT, M. et al. Generation of transgenic cattle by lentiviral gene transfer into oocytes. Biol. Reprod., v.71, p.405-409, 2004.

KUES, W.A.; NIEMANN, H. Advances in farm animal transgenesis. Prev. Vet. Med., v.102, p.146-156, 2011.

PFEIFER, A.; HOFMANN, A. Lentiviral transgenesis. In: KUHN, R.; WURST, W. (Eds.). Gene knockout protocols. 2.ed. USA: Humana Press, 2009. p.391-405.

WANG, X.; MCMANUS, M. Lentivirus production. J. Visual. Exp., v.32, e1499, 2009.

ZHANG, Y.; XI, Q.; DING, J. et al. Production of transgenic pigs mediated by pseudotyped lentivirus and sperm. PLoS One, v.7, e35335, 2012. 